\title{
Extended Fuzzy Analytical Hierarchy Process Approach in Determinants of Employees' Competencies in the Fourth Industrial Revolution
}

\author{
Phuc Van Nguyen ${ }^{1}$ \\ Rector, Ho Chi Minh City Open University (HCMCOU) \\ Ho Chi Minh City \\ Vietnam
}

Phong Thanh Nguyen ${ }^{2}$

Department of Project Management

Ho Chi Minh City Open University (HCMCOU)

Ho Chi Minh City, Vietnam

\author{
Quyen Le Hoang Thuy To Nguyen ${ }^{3}$ \\ Office of Cooperation and Research Management \\ Ho Chi Minh City Open University (HCMCOU) \\ Vietnam
}

\author{
Vy Dang Bich Huynh ${ }^{4}$ \\ Department of Learning Material \\ Ho Chi Minh City Open University (HCMCOU) \\ Ho Chi Minh City, Vietnam
}

\begin{abstract}
This paper explored the education factors and ranked their impacts on the employees' competencies development in Vietnam. Factors contributing to the employees' competencies in the Vietnamese context are proposed based on the literature review under the justification of experts' interviews. Then, the extended fuzzy analytical hierarchy process (EFAHP) approach was used to prioritize the importance of the factors affecting the employees' competency. The research finding confirmed the decisive role of teachers with the greatest weight of impact on the employees' competency, though there was a shift of teacher's role to that of facilitator in the Fourth Industrial Revolution education.
\end{abstract}

Keywords-Employees' competency; fuzzy logic; Extended Fuzzy Analytical Hierarchy Process (EFAHP)

\section{INTRODUCTION}

Competency is a multi-dimensional concept developed with two major descriptions, e.g., input approach (American school) and output approach (British school). In general, it refers to the ability to mobilize individual resources including knowledge, skills, and attitudes to successfully fulfill complex demands [1]. Competency is considered as a driver for any achievement, either at the micro or macro level [2]. A competency-based approach is beneficial for both the employer and employee. The employees can have a clear picture of labor market requirements for prior preparation during their school time. From the employer's perspective, a selection of the right staff with adequate competency has a significant impact on the organization's productivity and profitability. However, the gap competencies between supply and demand become more prominent - and Vietnam is no exception.

Vietnam is now encountering an increasing percentage of undergraduate unemployment while employers compete for recruitment of skilled workforces [3]. Furthermore, Vietnam ranked in the bottom percentile in human capital (70\%) and qualified workforce $(81 \%)$ despite impressive scores on the PISA test [4]. Education plays a decisive role in developing the labor force competency. [5]. Bloch [6] provided empirical evidence for the purpose of improving education to meet the labor market demand. However, employment-oriented competency education in Vietnam was virtually ignored [7]. Trung and Swierczek [8] further identified the drawbacks in higher education such as weak research skills and academic knowledge of lecturers, dominant lecturing and note-learning, and minimal interaction between students and teachers.

This paper aims at ranking the education factors that determine employee competency. The findings are expected to help inform Vietnam's human resources allocation in higher education to suit the needs of the labor market, especially in the Fourth Industrial Revolution.

\section{LITERATURE REVIEW}

Various researchers identified competencies shortages as the primary cause of the high unemployment rate of university graduates. The problem becomes even more severe when the degree is not a credential but a social decoration. Higher education is responsible for the misalignment between the competencies provided by the university and the ones demanded by the labor market. Several institutional factors are reviewed as the main contributors to the employee competencies: teacher, information and communication technologies (ICT), competency-based approach education (CBA), university and industry partnership, competency-based curriculum (CBC), and competency-based curriculum.

The teacher is one of the critical components in the educational process and significantly impacts on the student's performance in the following categories: (1) instructional delivery, (2) classroom management, and (3) students' competency [9-11]. In the context of Industry 4.0 with rapid technology development, teachers must prepare students to deal with the jobs, technologies, and problems that have not been previously taught [12].Therefore, lifelong learning is critical and the teacher becomes a facilitator whose major role is to inspire the students. An inspirational teacher can 
encourage students' learning interest, motivate them to fulfill tasks they never thought that they could do, and encourage them to be creative in planning and organization of activities. This leads to their competency improvement [13, 14]. According to Hattie [15], the lesson mastery of students increased $17 \%$ with the teacher as a facilitator compared to $4 \%$ when instruction is student-centered. As a result, better employee competency can be found in the setting where the teacher actively guides the study method instead of merely transmitting the lesson content. Teachers also play an important role in managing a class; this role was ranked as one of the top five factors contributing to student achievement and positive attitudes. In fact, Oliver, et al. [11] found a reduction of $22 \%$ negative behavior in classrooms systematically managed by the teacher.

Various studies considered the role of ICT in improving learning outcomes and subsequently learners' competency by providing them the tool for lifelong learning [16-18]. In fact, it is an essential educational resource in the context of Industry 4.0 for both teachers and students. With ICT, the traditional teacher's role in knowledge delivery is challenged. Thus, the facilitator role should be directed. In addition, teachers can understand and address students' different learning styles thanks to the support of ICT. The learning process can be customized to adapt to each individual characteristics. Also, distance learning is allowed, thus maximizing the learner's performance. Soparat, et al. [19] found that five key competencies of students, including communication, critical thinking, problem-solving, life skill and technological applications, can be developed with the use of ICT in education. In summary, ICT is valuable for competency development by supporting online collaboration, networking, differentiation and customization [20].

Competency-based approach education (CBA) is considered as an innovation in higher education because it awards students credits based on competency rather than time spent in class. It clearly indicates the required competencies mastered by learners. As a result, students have opportunities to decide their learning process and either shorten or lengthen the time to complete a degree. Also, students know well the gap between what they know and what they are able to do. With this approach, rigid lesson plans and conveyed content are not a primary focus. Desired outcomes should be defined before preparing the course content. The learners are expected to achieve capacity for actions as a result of mobilizing all resources [21]. Therefore, the ability to apply mastered class knowledge to the working environment is assessed instead of just theoretical knowledge. CBA is found as a solution to mismatching between a professional's education and labor market requirements [20]. However, the credibility of CBA greatly depends on assessment quality [22].

According to Guimón [23], skills development for students is one of the benefits of academia and industry collaboration. Slotte and Tynjälä [24] found a significant improvement in workforce professionals from this partnership. Nowadays, a growing competency gap between education and market demand has pushed the exchange between university and industry. The curriculum development process is evidence of the advantage of firm and university linkage [25]. Under the circumstances of technology development in the economy, education providers may successfully train the workforce if they closely align the curriculum in accordance with industry feedback. The contribution of industry to curriculum improvement can be diversified under various forms. Industry participation on the university academic board, in internships, and via adjunct faculty positions are potential activities provided by the firm to the university to promote student competency [26].

The development of students' core competencies is contemporarily the final goal of a university in designing a curriculum. It can solve the problem of the competency gap between the education and labor market demand once it mirrors the social and economic needs. A practical curriculum also motivates students and helps them realize their knowledge, skill and attitudes. Anastasiu, et al. [27] proposed a competency-based curriculum with three major parts of education including (1) professional courses and apllications, (2) internship and apprenticeship, and (3) soft skills courses and application. The first part of this curriculum aims at providing major knowledge while the two latter ones emphasize the knowledge application together with various skills such as teamwork, organizational culture, project management and entrepreneurship.

\section{ReSEARCH Methodology}

Analytical Hierachy Process (AHP), a modern structural analysis method invented by Saaty in 1980, is used to identify the factor weights [28-30]. This method is a combination of both qualitative and quantitative data in a logical hierarchy [31-34]. This method is flexible, visual, and helpful in criteria conflict-solving and for complex multi-criteria issues [35, 36]. As a result, the subjective and prejudiced attitude toward decision-making is alleviated $[37,38]$. The main contribution of the fuzzy set theory is the ability to express ambiguous data [39]. The fuzzy theory also allows mathematical operators and programmers to apply to the fuzzy domain [40]. Fuzzy set theory consists of a special set of mathematical tools that are particularly suited to handle incomplete information or the ambiguity of object classes or situations in the most flexible way [41]. The steps of the extended fuzzy analytic hiearchy process method (EFAHP) are as follows [28, 41-45]:

Let $X=\left\{x_{1}, x_{2}, \ldots, x_{n}\right\}$ be an object set, and $U=\left\{u_{1}, u_{2}, \ldots\right.$, $\left.u_{m}\right\}$ be a objective set. Then, the $m$ extent analysis values for each $i^{\text {th }}$ object for $m$ goals are obtained and shown as follows [46-49]:

$\tilde{M}_{g_{i}}^{j}$ where $i=1,2, \ldots, n ; j=1,2, \ldots, m$

All the $\tilde{M}_{g_{i}}^{j}$ are triangular fuzzy numbers (TFNs).

Step 1: Obtain priority weights

The value of fuzzy synthetic extent on the $i^{\text {th }}$ object is represented as Duru, et al. [50], [51]:

$$
S_{i}=\left(\sum_{i=1}^{m} l_{i}, \sum_{i=1}^{m} m_{i}, \sum_{i=1}^{m} u_{i}\right) \otimes\left(\frac{1}{\sum_{i=1}^{n} u_{i}}, \frac{1}{\sum_{i=1}^{n} m_{i}}, \frac{1}{\sum_{i=1}^{n} l_{i}}\right)
$$




\section{Step 2: Comparing degrees of possibility}

The degree of possibility of $M_{2}=\left(l_{2}, m_{2}, u_{2}\right) \geq M_{1}=\left(l_{1}, m_{1}\right.$, $\left.u_{1}\right)$ is defined as $V\left(M_{2} \geq M_{1}\right)$ and can be equivalently expressed as follows [52]:

$$
\begin{aligned}
& V\left(M_{2} \geq M_{1}\right)=\operatorname{hgt}\left(M_{1} \cap M_{2}\right)=\mu_{M_{2}}(d) \\
& = \begin{cases}1 & \text { if } m_{2} \geq m_{1} \\
0 & \text { if } l_{1} \geq u_{2} \\
\frac{l_{1}-u_{2}}{\left(m_{2}-u_{2}\right)-\left(m_{1}-l_{1}\right)} & \text { otherwise }\end{cases}
\end{aligned}
$$

where $d$ is the ordinate of the highest intersection point $D$ between $\mu_{M_{1}}$ and $\mu_{M_{2}}$, as shown in Fig. 1 .

Step 3: Obtaining the weight vector

The degree possibility for a convex fuzzy number to be greater than $k$ convex fuzzy numbers $M_{i}(i=1,2, \ldots, k)$ can be defined by Duru, et al. [50]:

$V\left(M \geq M_{1}, M_{2}, \ldots, M_{k}\right)=V\left[\left(M \geq M_{1}\right)\right.$ and $\left(M \geq M_{2}\right)$ and $\ldots$

$\left.\left(M \geq M_{\mathrm{k}}\right)\right]=\min V\left(M \geq M_{i}\right), i=1,2, \ldots, k$.

Assume that

$d^{\prime}\left(A_{i}\right)=\min V\left(S_{i} \geq S_{k}\right)$

for $k=1,2, \ldots, n ; k \neq i$.

Then, the weight vector is given by:

$W^{\prime}=\left(d^{\prime}\left(A_{1}\right), d^{\prime}\left(A_{2}\right), \ldots, d^{\prime}\left(A_{n}\right)\right)^{T}$

where $A_{i}(\mathrm{i}=1,2, \ldots, n)$ are $n$ elements.

Step 4: Calculate the normalized weight vector

Via normalization, the normalized weight vectors are:

$W=\left(d\left(A_{1}\right), d\left(A_{2}\right), \ldots, d\left(A_{n}\right)\right)^{T}$

$\mathrm{W}$ is a nonfuzzy number.

Step 5. Ranking of the factors

After getting the weights of the factors, the ranking of all factors is determined.

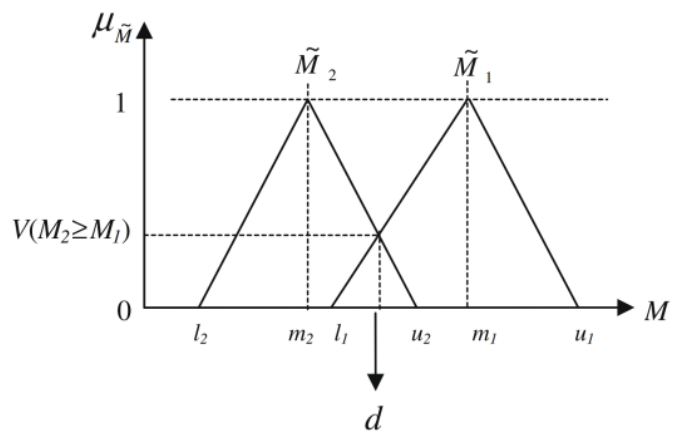

Fig. 1. The Intersection between M1 and M2.

\section{RESULTS AND DISCUSSION}

In general, the factors which determine employees' competency in Vietnam were developed with a combination of both literature review and expert interviews by using the extended fuzzy analytic hierarchy process (EFAHP) technique. The ranking of factors influencing on the employees' competency are in Table I.

Vietnam is a country governed by Confucian philosophy in the teacher-student relationship. The teacher's role is evaluated as the most significant factor in the student's competency. Traditionally, the teacher was the tank of knowledge. Nowadays, knowledge is a lifelong learning process. Therefore, a great teacher is the one who can inspire the lifelong learner. The research findings do confirm the theory and provide empirical evidence on the role of the teacher. It is the first target for policy intervention to improve students' competencies. In order to reach the goal, guidelines and tools are two important contributors. The teacher can be considered as a guideline while ICT is a tool for students to realize their goals. The authors found that ICT is a driver for the adoption of e-learning in Vietnam, which is also a means of lifelong learning. Therefore, it is ranked second among the determinants of employees' competency.

The collaboration between university and industry is not so strong in Vietnam. It has caused a major bottleneck to obtaining a skilled workforce. Knowledge cannot be transformed to competency without practice. Therefore, a process should be established to get firms involved in education such as curriculum development, internship, and joint supervision of Ph.D students to conduct research. This also leads to a change to the Competency-Based Approach from traditional Content-Based Approach. The research findings also revealed a lesser role of the curriculum in employee competency in the context of the Fourth Industrial Revolution. The gap between employees' competency and market demand will only widen with technology changes. According to Lin [53], about $9 \%$ of world jobs in 2030 will be in new occupations. Transdisciplinary curricula have to be prepared to tackle the global change. Therefore, the education curriculum should be geared toward training students how to learn instead of what to learn and thus flexibly equip them with sufficient competency for future jobs [54].

TABLE I. RANKING OF FACTORS INFLUENCING ON THE EMPLOYEES' COMPETENCY MODEL

\begin{tabular}{|l|l|}
\hline \multicolumn{1}{|c|}{ Factors } & Rank \\
\hline Teacher & 1 \\
\hline University and industry partnership & 3 \\
\hline Competency-based curriculum & 5 \\
\hline Competency-based approach education (CBA) & 4 \\
\hline Information and communication technologies (ICT) & 2 \\
\hline
\end{tabular}




\section{CONCLUSION}

This paper analyzed the contribution of each educational factor to employee competency by using the extended fuzzy analytic hierarchy process (EFAHP) technique. The findings confirmed the teacher's role, even in the context of the Fourth Industrial Revolution. Moreover, the finding found that method is more important than content. In the technology-driven economy, learners should be trained in methodology in order to quickly adapt to labor market demand. In addition, education should be treated and tailored to the markets' need in order to maximize the work benefit from individuals' competences. Educational factors should be well implemented in order to have a positive effect on employees' competency.

\section{ACKNOWLEDGMENT}

The authors gratefully acknowledge the Ho Chi Minh City Peoples Committee and Ho Chi Minh City Open University, Vietnam for supporting this research.

\section{REFERENCES}

[1] D. S. Rychen and L. H. Salganik, Key competencies for a successful life and well-functioning society. Hogrefe Publishing, 2003.

[2] D. C. McClelland, "Testing for competence rather than for" intelligence."," American psychologist, vol. 28, no. 1, p. 1, 1973.

[3] C. Bodewig and R. Badiani-Magnusson, Skilling up Vietnam: Preparing the workforce for a modern market economy. The World Bank, 2014.

[4] WEF, "Readiness for the Future of Production Report 2018," in "World Economic Forum's System Initiative on Shaping the Future of Production," 2018.

[5] S. Alainati, S. Alshawi, and W. Al-Karaghouli, "The effect of education and training on competency," 2010.

[6] M. Bloch, "Situated learning: Legitimate peripheral participation," Man, vol. 29, no. 2, pp. 487-489, 1994.

[7] D. Oliver, "The US Community College Model and Vietnam's Higher Education System," 2002.

[8] T. Q. Trung and F. W. Swierczek, "Skills development in higher education in Vietnam," Asia Pacific Business Review, vol. 15, no. 4, pp. 565-586, 2009.

[9] I. Arnold, "John Hattie: Visible learning: A synthesis of over 800 metaanalyses relating to achievement," International Review of Education, journal article vol. 57, no. 1, p. 219, May 022011.

[10] C. M. Evertson and C. S. Weinstein, Handbook of classroom management: Research, practice, and contemporary issues. Routledge, 2013.

[11] R. M. Oliver, J. H. Wehby, and D. J. Reschly, "Teacher classroom management practices: Effects on disruptive or aggressive student behavior," Society for Research on Educational Effectiveness, 2011.

[12] T. A. Nguyen, P. T. Nguyen, and V. Peansupap, "Explaining model for supervisor's behavior on safety action based on their perceptions," ARPN Journal of Engineering and Applied Sciences, Article vol. 10, no. 20, pp. 9562-9572, 2015.

[13] J. Cornelius-White, "Learner-centered teacher-student relationships are effective: A meta-analysis," Review of educational research, vol. 77, no. 1, pp. 113-143, 2007.

[14] P. Van Nguyen, P. T. Nguyen, V. D. B. Huynh, and Q. L. H. T. T. Nguyen, "Critical factors affecting the happiness: A Vietnamese perspective," International Journal of Economic Research, Article vol. 14, no. 4, pp. 145-152, 2017.

[15] J. Hattie, Visible learning: A synthesis of over 800 meta-analyses relating to achievement. routledge, 2008.

[16] F. O. Pineida, "Competencies for the 21st century: integrating ICT to life, school and economical development," Procedia-Social and Behavioral Sciences, vol. 28, pp. 54-57, 2011.
[17] P. T. Nguyen et al., "Construction project quality management using building information modeling 360 field," International Journal of Advanced Computer Science and Applications, Article vol. 9, no. 10, pp. 228-233, 2018.

[18] P. T. Nguyen, T. A. Nguyen, Q. L. H. T. T. Nguyen, and V. D. B. Huynh, "Application of SWOT for construction company quality management using building information modelling," Journal of Mechanics of Continua and Mathematical Sciences, vol. 13, no. 05, pp. 25-33, 2018.

[19] S. Soparat, S. R. Arnold, and S. Klaysom, "The development of Thai learners' key competencies by project-based learning using ICT," International Journal of Research in Education and Science, vol. 1, no. 1, pp. 11-22, 2015.

[20] O. Gavrishina and Y. Zaharov, "Competency-Based Approach in Training Mathematicians: Challenges of Time," Procedia-Social and Behavioral Sciences, vol. 214, pp. 212-221, 2015.

[21] N. Hirtt, "L’approche par compétences: une mystification pédagogique," L'école démocratique, vol. 39, pp. 1-34, 2009.

[22] K. L. McClarty and M. N. Gaertner, "Measuring mastery: Best practices for assessment in competency-based education," AEI Series on Competency-Based Higher Education, 2015.

[23] J. Guimón, "Promoting university-industry collaboration in developing countries," World Bank, vol. 3, 2013.

[24] V. Slotte and P. Tynjälä, "Industry-university collaboration for continuing professional development," Journal of Education and Work, vol. 16, no. 4, pp. 445-464, 2003.

[25] P. Matkovic, P. Tumbas, M. Sakal, and V. Pavlicevic, "Curriculum Development Process Redesign Based on University-Industry Cooperation," in Proceedings of the 6th International Conference on Education and New Learning Technologies (EDULEARN), 2014, pp. 4113-4123.

[26] M. Perkmann and K. Walsh, "University-industry relationships and open innovation: Towards a research agenda," International Journal of Management Reviews, vol. 9, no. 4, pp. 259-280, 2007.

[27] L. Anastasiu, A. Anastasiu, M. Dumitran, C. Crizboi, A. Holmaghi, and M. Roman, "How to Align the University Curricula with the Market Demands by Developing Employability Skills in the Civil Engineering Sector," Education Sciences, vol. 7, no. 3, p. 74, 2017.

[28] V. D. B. Huynh, P. V. Nguyen, Q. L. H. T. T. Nguyen, and P. T. Nguyen, "Application of Fuzzy Analytical Hierarchy Process based on Geometric Mean Method to Prioritize Social Capital Network Indicators," International Journal of Advanced Computer Science and Applications, vol. 9, no. 12, pp. 182-186, 2018.

[29] C. Meidiana, I. D. Nurfitriya, and K. E. Sari, "Multi-criteria evaluation for determination of anaerobic di-gester location in rural area," International Journal of Recent Technology and Engineering, Article vol. 7, no. 4, pp. 153-157, 2018.

[30] V. D. B. Huynh, P. Van Nguyen, Q. H. T. T. Nguyen, and P. T. Nguyen, "Application of Fuzzy Analytical Hierarchy Process based on Geometric Mean Method to prioritize social capital network indicators," International Journal of Advanced Computer Science and Applications, Article vol. 9, no. 12, pp. 182-186, 2018.

[31] P. Choudhary and U. Singh, "Ranking terrorist organizations network in India using combined Sna-Ahp approach," International Journal of Recent Technology and Engineering, Article vol. 7, no. 4, pp. 168-172, 2018.

[32] P. Van Nguyen, P. T. Nguyen, Q. L. H. Thuy, T. Nguyen, and V. D. B. Huynh, "Calculating Weights of Social Capital Index Using Analytic Hierarchy Process," International Journal of Economics and Financial Issues, vol. 6, no. 3, pp. 1189-1193, 2016.

[33] P. Van Nguyen, P. T. Nguyen, Q. L. H. T. T. Nguyen, and V. D. B. Huynh, "Calculating weights of social capital index using analytic hierarchy process," International Journal of Economics and Financial Issues, Article vol. 6, no. 3, pp. 1189-1193, 2016.

[34] D. L. Luong, D. H. Tran, and P. T. Nguyen, "Optimizing multi-mode time-cost-quality trade-off of construction project using opposition multiple objective difference evolution," International Journal of Construction Management, Article in Press 2018. 
[35] P. T. Nguyen, P. Van Nguyen, Q. L. H. T. To Nguyen, and V. D. B Huynh, "Project success evaluation using TOPSIS algorithm," Journal of Engineering and Applied Sciences, Article vol. 11, no. 8, pp. 1876-1879, 2016.

[36] P. T. Nguyen and V. Likhitruangsilp, "Identification risk factors affecting concession period length for public-private partnership infrastructure projects," International Journal of Civil Engineering and Technology, Article vol. 8, no. 6, pp. 342-348, 2017.

[37] A. L. Ode, L. Samang, and I. Ramli, "Analysis of the priority of the improvement of the provincial road status in mamminasata region at south sulawesi based on analytic hierarchy process," International Journal of Innovative Technology and Exploring Engineering, Article vol. 8, no. 4S, pp. 13-17, 2019.

[38] K. Madhuvanthi, M. K. Nallakaruppan, N. C. Senthilkumar, and S. Siva Rama Krishnan, "Car sales prediction using machine learning algorithmns," International Journal of Innovative Technology and Exploring Engineering, Article vol. 8, no. 5, pp. 1039-1050, 2019.

[39] P. T. Nguyen, N. B. Vu, L. Van Nguyen, L. P. Le, and K. D. Vo, "The Application of Fuzzy Analytic Hierarchy Process (F-AHP) in Engineering Project Management," in 2018 IEEE 5th International Conference on Engineering Technologies and Applied Sciences, ICETAS 2018, 2019.

[40] N. Geetha Lakshmi and D. Shanmuga Priyaa, "Handling of indeterminacy for trust aware energy consumption using adaptive intuitionistic fuzzy environment in wireless sensor networks," International Journal of Recent Technology and Engineering, Article vol. 7, no. 4, pp. 239-247, 2018.

[41] N. T. Phong and N. L. H. T. T. Quyen, "Application fuzzy multi-attribute decision analysis method to prioritize project success criteria," AIP Conference Proceedings, vol. 1903, no. 1, p. 070011, 2017.

[42] P. T. Nguyen, V. Likhitruangsilp, and M. Onishi, "Prioritizing factors affecting traffic volume of public-private partnership infrastructure projects," International Journal of Engineering \& Technology, vol. 7, no. 04, pp. 2988-2991, 2018.

[43] N. T. Phong, V. N. Phuc, and T. T. H. L. N. Quyen, "Application of Fuzzy Analytic Network Process and TOPSIS Method for Material Supplier Selection," Key Engineering Materials, vol. 728, pp. 411-415, 2017.
[44] N. T. Phong and N. L. H. T. T. Quyen, "Application fuzzy multi-attribute decision analysis method to prioritize project success criteria," in AIP Conference Proceedings, 2017, vol. 1903.

[45] T. N. Phong, V. N. Phuc, and T. T. H. L. N. Quyen, "Application of fuzzy analytic network process and TOPSIS method for material supplier selection," in Key Engineering Materials vol. 728, ed, 2017, pp. 411-415.

[46] M. K. Moghadam, A. R. M. Jahromi, and A. S. Nooramin, "A fuzzy AHP decision support system for selecting yard cranes in marine container terminals," WMU Journal of Maritime Affairs, vol. 10, no. 2, pp. 227240, 2011.

[47] İ. Ertuğrul and N. Karakaşoğlu, "Comparison of fuzzy AHP and fuzzy TOPSIS methods for facility location selection," The International Journal of Advanced Manufacturing Technology, vol. 39, no. 7, pp. 783795, 2008.

[48] N. T. Phong, V. Likhitruangsilp, and M. Onishi, "Developing a stochastic traffic volume prediction model for public-private partnership projects," in AIP Conference Proceedings, 2017, vol. 1903.

[49] P. T. Nguyen, V. Likhitruangsilp, and M. Onishi, "Prioritizing factors affecting traffic volume of public-private partnership infrastructure projects," International Journal of Engineering and Technology(UAE), vol. 7, no. 4, pp. 2988-2991, 2018.

[50] O. Duru, S. T. Huang, E. Bulut, and S. Yoshida, "Multi-layer quality function deployment (QFD) approach for improving the compromised quality satisfaction under the agency problem: A 3D QFD design for the asset selection problem in the shipping industry," Quality \& Quantity, pp. 1-22, 2013.

[51] J. R. S. C. Mateo, "FAHP," Multi Criteria Analysis in the Renewable Energy Industry, pp. 77-93, 2012.

[52] U. Cebeci and D. Ruan, "A multi-attribute comparison of Turkish quality consultants by fuzzy AHP," International Journal of Information Technology \& Decision Making, vol. 6, no. 01, pp. 191-207, 2007.

[53] J. Lin, "Technological adaptation, cities, and new work," Review of Economics and Statistics, vol. 93, no. 2, pp. 554-574, 2011.

[54] V. D. B. Huynh, Q. L. H. T. T. Nguyen, P. Van Nguyen, and P. T. Nguyen, "Application Partial Least Square Structural Equation To Develop A Job Search Success Measurement Model," Journal of Mechanics of Continua and Mathematical Sciences, vol. 13, no. 5, 2018. 